\title{
FóRIZs Sándor \\ A magyar határőrség és az 1968-as csehszlovákiai bevonulás
}

(Hungarian Border Patrol and the 1968 Invasion of Czechoslovakia)

Absztrakt

1968. augusztusban a Varsói Szerződés több tagállama katonai intervenciót hajtott végre Csehszlovákiában. Jelen publikáció a magyar határőrség szerepét, tevékenységét vizsgálja ezen események során a Magyar Nemzeti Levéltárban feltalálható dokumentumok elemzése útján. A szerző bemutatja a határőrség vezetésének felkészülését a határátlépés biztosítására, az alkalmazott vezetési és szolgálat ellátási módszereket, az erők csoportosításának rendjét, a bekövetkezett eseményeket. Szó esik az ország belsejében foganatosított intézkedésekről és néhány szomszédos ország reagálásáról a történtekre.

Kulcsszavak

határőrség ; határátlépés ; határzár ; határövezet ; bevonulás Csehszlovákiába 1968

\section{Abstract}

In August 1968, several member states of the Warsaw Pact participated in a military intervention against Czechoslovakia. Using documents stored at the National Archives of Hungary, the work looks at the role and endeavors of the Hungarian Border Patrol (HBP) in this military action. The author introduces the preparatory work undertaken by HBP leadership to secure border crossings, the applied methods of commanding and service, the grouping of forces and the actual events as they played out. Also covered in the work are the measures undertaken within the country and the reactions of a few neighboring countries to the events.

Key words:

Hungarian Border Patrol ; border crossing ； border barrier ； border zone ； 1968 Invasion of Czechoslovakia

$*$

Open Researcher and Contributor ID = Nyílt Kutató és Közremüködő Azonosító (ORCID) : https://orcid.org/0000-0001-6019-3295

Institutional attachements = Szerző intézményi kötődései :

- Bertalan Szemere Scientific Society of History of Hungarian Law Enforcement = Szemere Bertalan Magyar Rendvédelem-történeti Tudományos Társaság

- National University of Publik Service Faculty of Law Enforcement $\quad=$ Nemzeti Közszolgálati Egyetem Rendészettudományi Kar @: drforizsdandor@invitel.hu 
A Varsói Szerződés néhány tagállamának csapatai 1968. augusztusban katonai intervenciót hajtottak végre Csehszlovákiában. ${ }^{1}$ Publikációmban a BM Határőrség ezen 1968-as csehszlovákiai bevonuláskor játszott szerepével, tevékenységével foglalkozom, alapvetően a Magyar Nemzeti Levéltár (a továbbiakban MNL) Határőrség Országos Parancsnokság fellelhető dokumentumai alapján. Az 1968-as év 9. és 10. számú dobozai tartalmazzák a kapcsolódó okmányokat „MNL HOP XIX-B-10 9. sz. doboz 1968 év” kódjelzésekkel. A 9. számú doboz 73. folyószáma húsz különbözö, számunkra igen értékes dokumentumot tartalmaz, melyeket egymástól pusztán a címük különböztet meg, de azonos levéltári nyilvántartási számon szerepelnek. Ezért előfordulhat különböző anyagokra történő hivatkozás esetén az egybeeső levéltári megjelölés.

Az események idején a magyar állami és pártvezetés naponta úgynevezett „hangulatjelentések”-et kért a határőrség parancsnokságától, melyek az állomány viselkedésére, a polgári lakosságra és a határőrség tevékenységére vonatkozóan értékes információkat tartalmaznak. Az országos parancsnoksági intézkedések, parancsok; az érintett határőr kerületek jelentései; parancsnokaik elhatározásai; a balassagyarmati kerület folyamatosan vezetett hadmüveleti naplója szintén fellelhetőek ezekben a dobozokban, egyedi adatokat szolgáltatva egy esetleges rendészeti jellegü határbiztosítás megszervezésére vonatkozóan. Bár a történelemben pontosan egyformán semmi sem ismétlődik meg, az ekkor szerzett tapasztalatok még hasznosak lehetnek egy elkövetkező esetben.

A csehszlovákiai válság kialakulásához, az ország belpolitikai helyzete mellett, egyebek közt jelentősen hozzájárultak a két rendszer közt dúló ideológiai háború egyik megnyilvánulásaként a Münchenben múködő amerikai rádióállomások is. A Szabad Európa rádió például napi húsz órát Csehszlovákiába sugárzott. Az ideológiai konfrontáció és ezek belügyi sajtóban tükröződései három publikációban is feldolgozásra kerültek. ${ }^{2}$

\section{A határőrség lehetőségei a bevonulás idején}

A határőrség ezen események során játszott szerepét jelentősen befolyásolták képességei, melyeket megítélésem szerint az akkori politikai/katonai vezetés jól látott és ezeknek megfelelően határozták meg a testület feladatait. ${ }^{3}$

A szervezet ebben az időben jogszabályilag a fegyveres erők részét képezte — a szovjet indíttatású pártállami hagyományokat követve ${ }^{4}-1953$ óta a Belügyminisztérium szervezetébe tartozott, történelmileg korábbi kis megszakításokkal, (1945-1949. a Honvédelmi Minisztérium, 1950-1953. a Minisztertanács alárendeltségében). ${ }^{5}$

Álláspontom szerint a vizsgált időszak magyar határőrsége nem rendelkezett olyan képességekkel, amelyek alapján katonai-szakmai vonatkozásban ténylegesen fegyveres erőnek lehetne tekinteni.

A testületi struktúra elemei — országos parancsnokság; regionális szinten kerületek illetve az egy Győri Önálló Zászlóalj; az előzőeken belül őrsök és forgalomellenőrző pontok voltak, amelyek lényegében nem tartalmaztak katonai kötelékeket. Rendelkeztek a kerületek századokkal (híradó-, törzs-, szállító-, vegyivédelmi század) de ezek kiszolgáló, logisztikai, szállítási tevékenységet végeztek, fegyveres harcra nem voltak képesek. A forgalomellenőrzö pontok beosztottai akkor is lényegében idegenrendészeti tevékenységet láttak el ennek megfelelő felkészítéssel.

A fegyverzet a kézifegyverek szintjén maradt, a testület számára gépkarabélyt, géppuskát és páncéltörő gránátvetőt rendszeresítettek. Hiányzott minden olyan tüzérségi eszköz és páncélozott jármü mely egy harcászati szituációban az eredményes tevékenység esélyét biztosíthatta volna. Nem volt elegendő szállító jármủ az alegységek létszámának egyidejü mozgatására és elegendő olyan felszerelés, amely lehetővé tette volna, hogy a szabadban huzamosabb ideig tartózkodjanak, különösen kedvezőtlen időjárási körülmények között és ott megfelelő ellátást kapjanak.

A sorállomány kiképzésében elhanyagolható részt képviselt a harcászati felkészítés, az is csak az egyes harcos és a raj szintjét érintette. A fő profilt a járőrszolgálat, a személyek igazoltatása, elfogása, kísérése alkotta, a szolgálatellátás alapja a járőr kötelék lett. A ténykedést szabad terepviszonyokra oktatták. Lakott területen történő védelmi vagy támadó eljárásokat, de még biztosítási jellegü tevékenységeket sem dolgoztak fel.

Hiányzott a felkészítésből a civil demonstrálókkal szembeni eljárás és nem rendelkeztünk az ehhez szükséges felszereléssel, eszközökkel. Tömegoszlatásra, tömegrendezvények kezelésére lényegében a határőrségnek nem volt lehetősége.

Nem létezett olyan állandó jellegű alegység, szakasz, század a rendszerben, amelyiknek kizárólag harcászati tevékenység lett volna az alaprendeltetése. De nem múködött olyan állandó jellegü kötelék sem, mely, mint tartalék funkcionált volna akár valamilyen rendvédelmi tevékenység céljából is. Az egyetlen szervezet, amelyhez szükség esetén a vezetők fordulhattak — amennyiben hirtelen élőerő 
alkalmazása vált szükségessé - a kerületek tisztes iskolái voltak. Ilyenkor természetesen félbe kellett szakítani az ott folyó kiképzést. Ezekre az esetekre alapvetően a nagyobb kiterjedésű razziák vezetése során került sor, amikor is a személyi állomány, felkészítésének megfelelően zárásban és kutatásban, terepen, nappali és éjszakai viszonyok között általában jól teljesített. Elvileg lehetett még erőt és eszközöket az őrsökről biztosítani, összevonni. Mondjuk őrsönként öt-tíz főtt a szükséges fegyverzettel, felszereléssel. Viszont ezek kötelékbe szervezése, kiegészítő felkészítése, összeszoktatása, összekovácsolása jelenős időt, energiát, helyet igényelt, miközben a folyó határőrizetet esetleg meggyengítették, ami ellentétes volt a politikai vezetés elvárásaival. A magyar kormány a csehszlovákiai bevonulás idején legalább két további államhatáron - osztrák, jugoszláv - számolt feszültséggel és ez korlátozta az onnan elvonható határör erők nagyságát.

A tisztek ugyan katonai föiskolát végeztek, de határör szakon kaptak felkészítést, amelynek a tananyaga elsősorban a határőrizeti feladatok eredményes végzését szolgálta és csak másodlagos volt a harcászati teendőkre történő felkészítés.

Több olyan szervezeti elem - átkelöhelyek, felderítő szervek, a kerülettörzsekben osztályok és alosztályok funkcionáltak (pl. pénzügy) - amelyek mozgatása ilyen kritikus helyzetben problémát jelentett és hátra kellett volna hagyni azokat. ${ }^{6}$

A határőrség azonban a Magyar Néphadsereghez viszonyítottan kevésbé hatékony harcászati képességei ellenére is több területen jelentős segítséget tudott nyújtani a tervezett katonai müvelethez. Olyan előnyös képességekkel, tulajdonságokkal rendelkezett melyeket mindenképpen igénybe kellett venni:

- A csehszlovák-magyar államhatáron, az átkelöhelyeken egymással együttmüködve dolgoztak a két ország határforgalmat ellenőrző szervezetei. Jól ismerték egymást, napi munkakapcsolatban álltak. A Magyar Néphadsereg kijelölt csapatainak a tervezett határátlépése közutakon történt harc- és szállító járművekkel. Ennek zavartalan megvalósításához ki kellett kapcsolni a túloldali ellenőrző szerveket, eltávolítani a forgalmi sorompókat és leállítani mindkét irányból a polgári forgalmat. Ilyen feladatra a határőr erők voltak a legalkalmasabbak, akiknek már a személyes ismeretségük is bizonyos garanciát jelenthetett a csehszlovák szervek részéről esetleg jelentkező fizikai ellenállás elkerülésére. Ugyanez a szituáció vonatkozott a vasúti átkelőhelyekre és a zöldhatár őrizetét ellátó csendőr őrsök elfoglalására, a fegyverek ottani fegyverszobákban történő biztonságos elzárására.

- A túloldalra vonatkozó fontos, naprakész adatokkal rendelkeztek a határőr felderítő szervek. A kerületeknek lehetőségük nyílt összefüggő csapatfigyelési rendszer müködtetésére, szükség esetén a főirányokban tiszti figyelő pontok alkalmazására az inváziót megelőző utolsó napokban is.

- Az államhatár belső oldalán lehetőség nyílt ellenőrzött területsáv, határövezet létrehozására, amelynek segítségével a külföldieket, nemkívánatos érdeklődő személyeket az eseményektől távol lehetett tartani.

- A megerősített határőrségi járőrrendszer biztosíthatta azon személyek - alapvetően csehszlovák állampolgárok - elfogását, akik az események idejére létrehozott határzáron keresztül szándékoztak tiltott határátlépést elkövetni.

\section{A határőrségi vezetés felkészülése}

A határőrségi vezetés az országos parancsnokság és a kerület-parancsnokságok szintjén készült fel a várható határátlépésre. Az országos irányítás 1968. VII. 28-án parancsban határozta meg a teendőket.

A rejtett vezetés egyik módszere az úgynevezett „borítékos” megoldás volt. A fedőnévvel ellátott boríték, jelen esetben pl. „Bodrog”, tartalmazta írásban a végrehajtandó feladatokat. Az eseményeket megelőzően akár hónapokkal is ki lehetett adni, megpihent az illető vezető páncélszekrényében. Az ilyen jellegü okmányok többnyire sorszámozva tartalmazták a szükséges rendszabályokat. A helyzet aktivizálódása esetén távmondatban rendelték el felbontását és a feladatok végrehajtásának megkezdését. Amennyiben a boríték készítését követően hosszabb idő telt el és némileg változtak a tennivalók, úgy a távmondatban feltüntették, melyik számú rendszabályt nem kell végrehajtani, illetve konkrétan megadták az újonnan jelentkezett kiegészítő feladatokat. A borítékos megoldást a Belügyminisztérium is alkalmazta a „lefelé” irányuló intézkedésekre, az őrsparancsnokok páncélszekrénye volt a legalsó szint, ahol még ilyen okmányok funkcionáltak. Nem csak a csehszlovákiai eseményekkel kapcsolatban, a harckészültségi riasztásokra, magasabb harckészültségi fokozatba helyezéshez is léteztek borítékok. A Belügyminisztérium nem rendelkezett a határőrségre lebontva elektronikus kódoló és dekódoló eszközökkel, így kénytelen volt ehhez a megoldáshoz folyamodni, melynek azonban több lehetséges hibája is volt. 
A katonai beavatkozásra történő felkészüléshez külön tervet dolgoztak ki mely a ,»Bodrog «fedönevü gyakorlattal kapcsolatos intézkedések” címet viselte. ${ }^{7}$ Kiadására 1968. VII. 28-án került sor. Az eseményt a határörség törzsfönökének, BÁGYI János határör ezredesnek a jelentéséből ismerjük. „Az intézkedések gyors végrehajtásának segitésére bizottságokat jelöltem ki és részükre 28-án 19,00 órakor eligazitást tartottam. A »Bodrog "fedönevü intézkedési tervet is magukhoz véve 28-án 20,0020.30 közötti idöben személygépkocsival (a kerületekhez).... útba indultak." $23^{30}$-ig beérkeztek Miskolcra, Balassagyarmatra, Győrbe három-három fővel. Az 1-8. és 11. kerületektől tiszti futárokat rendeltek fel, a kerületek feladatait tartalmazó borítékokkal 1968. VII. 29-én 05느- re visszaérkeztek szolgálati helyeikre. A jelentésböl látható, hogy a határátlépés előkészítése már 1968. VII. 28-ára teljesen befejeződött, ezt követően már csak a szokásos pontosításokra volt szükség.

\section{Az országos parancsnok parancsa}

A legfőbb vezetési okmány az országos parancsnok parancsa ${ }^{9}$ lett melyet 1968 . VII. 28-án adott ki az 1., 2., 3., 4., 5., 6. 7., 8., 9. 10., 11., kerületek részére. A határőrség összesen 11 kerülete úgynevezett hadrendi számozással rendelkezett. A csehszlovák államhatáron három határör kerület (Csorna, Miskolc, Balassagyarmat és a Győri Önálló Zászlóalj helyezkedett el. A parancsot nem egyforma, hanem differenciált tartalommal küldték meg a címzetteknek, „Szigorúan titkos” „Különösen fontos” minősítéssel. Aláírta géppel SzABÓ Gusztáv vezérőrnagy országos parancsnok, kézzel „h”. jelzés hozzáírva, „Bágyi János ezds., BM Határörség Törzsfönöke”10. A parancsnok feltehetően távol volt.

Az okmányhoz kiegészítésül hozzáirták: „Korlátozás: A bevezetett intézkedésekröl párt, állami és társadalmi szervek vezetöit tájékoztatni nem kell."11

Néhány feladat az okmányból:

- 1. kerület (Csorna): Hegyeshalomi Forgalomellenőrző Ponton a csehszlovák állampolgárok kiléptetését be kell szüntetni. Rajkán a határforgalmat teljesen megszüntetni, az 1-4 őrsökön megerősített szolgálatot rendelnek el, a rajkai átkelőhely állományával megerősítik az őrsöket. A kerület határszakaszán határövezetet létesítenek Halászi „E” Bezenye „D” Hegyeshalom „K” vonalában.

- 2. kerület (Szombathely): „A Forgalom Ellenörzö Ponton azonnal szüntesse meg a csehszlovák állampolgárok kiléptetését, azokat irányitsa vissza. Számoljon azzal, hogy ennek következtében csehszlovák állampolgárok megkísérlik az államhatárt illegálisan átlépni, vagy azon gépjármüvel eröszakosan áttörni. Az állományt készitse fel ezen cselekmények bekövetkezésének megakadályozására. Ha a helyzet megkívánja - aktivitás fokozódik - azonnal térjen át a kerület egész határszakaszán megerösitett szolgálatra. "12

- 3. kerület (Zalaegerszeg): „akadályozza meg, hogy csehszlovák állampolgárok Jugoszláviába vagy Ausztriába tiltott módon kijussanak. "13

- 4. kerület (Nagykanizsa): „, a tisztes iskolát tartsa készenlétben”14

- 5. kerület (Pécs): „A Dunán közlekedö csehszlovák személy és teherhajók kiléptetését szüntesse meg. A bejövöket be kell léptetni és fel kell tartóztatni." ${ }^{15}$ „Megerösitem a 6. karhatalmi zászlóaljtól 100 fóvel és 4 db tehergépkocsival."16 Érdekes, hogy Pécsi Határör Kerület nem engedheti ki a csehszlovák hajókat Jugoszláviába és mind a pécsi, mind pedig a 6. kiskunhalasi határör kerület karhatalmi megerősítést kap. Nyilvánvalóan valamilyen jellegü nehézséggel számol a vezetés jugoszláv viszonylatban, esetleg a kifelé irányuló csehszlovák határsértési kísérletek növekedésével.

„A megerösitö eröket és a tisztes iskolát az „örsök megerösitésére, zárási - kutatási és egyéb harci feladatok végrehajtására alkalmazza."17

- 6. kerület (Kiskunhalas): megerősítik 100 fövel és négy tehergépkocsival a 3. karhatalmi zászlóaljtól.

- Győri Önálló Zászlóalj ,július.29-én 08,00 órakor jelentkezzen Mamajlov vezérörnagy elvtársnál abban a komáromi laktanyában, amelyben Guszev ezds. elvtárs a parancsnok. Munkatérképét vigye magával."18 A Győri Önálló Zászlóalj speciális helyzetben van a Duna, mint vízi határszakasz miatt, melyen keresztül érintkezik Csehszlovákiával. Ez a parancs megerősítette azt, hogy az 5. karhatalmi zászlóaljtól 100 fővel, négy tehergépkocsival, a 4. karhatalmi zászlóaljtól pedig 50 fővel és két tehergépkocsival 50 fős tartalékot kellett felállítani. A csehszlovák hajók kiléptetését beszüntették és a vízi határszakasz tekintetében szintén határövezetet jelöltek ki.

- A Ferihegyi repülőtérnek a menetrend szerint induló, csehszlovák területen leszálló gépeket további parancsig indítani nem volt szabad, csehszlovák állampolgárokat kiléptetését pedig semmilyen irányba sem engedélyezték.

Szembetünő, hogy a viszonylag jelentős sorállománnyal rendelkező határőrség erőit sem tartották elegendőnek, amennyiben a csehszlovák államhatáron komolyabb események következnek be, külö- 
nösen, ha közben a nyugati és déli határszakaszokon is szigorítani kellett volna a határőrizetet, mert esetleg az országban tartózkodó csehszlovák állampolgárok kiszökést kísérelhettek volna meg. A Belügyminisztérium szerencséjére még rendelkezésre állt a karhatalom.

A miskolci és a balassagyarmati határör kerületek részére meghatározott feladatok a parancsban szinte azonosak, nyilvánvalóan a hasonló helyzetük miatt. Ezért elegendőnek gondolom csupán a miskolci határőr kerület anyagát bemutatni, mivel az események fő teherviselője egyformán ez a két határör kerület volt.

\section{A miskolci kerület részére szabott feladatok}

„A Magyar Néphadsereg és a Szovjet Hadsereg közös hadgyakorlatának biztositásával kapcsolatban az alábbiakra intézkedem:"19 (Visszatérő formula az okmányokban a „közös hadgyakorlat” megnevezés, bár az érintettek nagyon jól tudták, miről van szó.)

Rendszabályok:

- A teljes működési területen áttérés megerősített szolgálatra, vagyis a szolgálati idő megemelése. (Az 1968. VIII. 20-án elrendelt megerősített szolgálatot 1968. IX. 7-én vonták vissza.)

- Egy fős járörözési rendszer megszüntetése.

- A kerületet „megerősíti”, azaz plusz erőt ad a rendelkezésére, az 1. és 2. karhatalmi zászlóaljtól, a 2. és 3. kerületek tisztes iskoláitól 100-100 fövel, 4-4 tehergépkocsival. A megerösítésre biztosított személyi állományból 22 fő tiszt, 48 fő tisztes, 330 fő pedig határőr illetve karhatalmista volt.

- „A megerösitésböl hozzon létre 100 fös tartalékot 4 szakaszos század szervezésben 6 tiszttel, 12 tisztessel, 82 határörrel illetve honvéddel $4 \mathrm{db}$. tehergépkocsival.

Készitse fel a megerösitést: egyes irányokban önállóan illetve együttmüködésben a rendör, honvéd, munkásőr, karhatalmi erőkkel harci feladat ellátására, razziára, zárásra, kutatásra, örizetesek szállitására, biztositására, örsök megerösitésére. "20 11 őrs megerösítését rendelte el, ezekre biztosítani kellett egy-egy tehergépkocsit, minden örsre vezényelni két fö tisztet (az 5., 8., 14. örsökre három föt), a felderítő alosztályt három fö tiszttel és egy fő tiszthelyettessel erősítették meg.

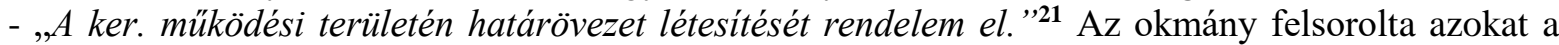
településeket, amelyeket az övezet érintett. Az övezetben bent lévő személyeket ki kellett engedni, utak, csomópontok ellenőrzését meg kellett szervezni. A mozgáskorlátozás magyar állampolgárokra nem vonatkozott.

- „A tisztes iskolán a kiképzést megszüntetem, a kiképzö keretet vezényelje az alegységek megerösitésére." 22

- Szabadságolásokat, szabadnapokat megszakították és a személyi állományt visszarendelték 24 órán belül.

- Mindennemü értekezletet, tanfolyamot és összevonást azonnal megszüntettek, a résztvevőket pedig visszaindították a szolgálati helyükre.

- „Határforgalmat azonnal szüntesse be valamennyi forgalomellenörzö ponton, a FEP-ek állományát az objektum őrizetére és a szomszédos örsök megerösitésére alkalmazni."

- „A helyzetnek megfelelöen biztositsa a szovjet, illetve magyar hadsereg alakulatainak a ki és beléptetését a lezárt FEP-eken."23

- „Anyagi vonatkozásban, a szerencsi kik. pont objektumát adja át az 1. kh zlj-nak, ruhacsere, étkeztetés, elhelyezés, tankolás a ker fea-a". ${ }^{24}$

- Külsősöket tájékoztatni nem lehetett.

- Az országos parancsnokság két óránként jelentést kért.

A kerületeknek „BODROG” időszakra, azaz a csehszlovákiai bevonulás idejére, 12 különbözö vezetési okmány készítését rendelték el, ezek voltak:

- ellenőrzési terv;

- terv a „Cs” és a „B” időszakra (a „Cs” időszak a határátlépés konkrét idejét és az ahhoz kapcsolódó azonnali feladatokat tartalmazta, a „B” időszak pedig ezt követte);

- a kerület-parancsnok írásos elhatározása;

- erö-eszköz elosztás;

- előzetes intézkedések terve;

- kimutatás a forgalomellenőrző pontok munkájáról;

- hadmüveleti napló;

- munkatérképek;

- együttmüködési tervek;

- a híradás biztosításának terve; 
- az anyagi-technikai biztosítás terve.

Természetesen a határőrség az akkor rá jellemző precizitással minden feladat végrehajtását részletes megtervezte, okmányokban kidolgozta és az érintettekkel megbeszélték.

A balassagyarmati határőr kerület parancsnokának elhatározásában szerepelt az is hogy, miként képzelte el a csehszlovák fegyveres szervek lefegyverzését: „Minden alegység müködési területével szemben levö csehszlovák FEP. és csendörség állományát, az alegységtöl kimenö erö alkalmazásával megnyugtatásra szólitom fel, magunk mellé állitom, ellenállás esetén lefegyvereztetem és a további intézkedésig ellenörzés alatt tartom. "25

A kerület müködési területen járőrcsoportokat alkalmazott és $8 \mathrm{~km}$-es mélységü határövezetet hozott létre.

A balassagyarmati határőr kerület felkészülése annak hadmüveleti naplója ${ }^{26}$ alapján ismerhető meg, melyet kézzel vezettek. Az első bejegyzés1968. VII. 28-án született.

Az eseményekre történő konkrét felkészülés már 1968. VII. 28 -án megkezdődött. Ekkor a balassagyarmati határőr kerület parancsnoka és a Határőrség Országos Parancsnokság képviselői este Isaszegen találkoztak a Magyar Néphadsereg érintett hadosztályának a vezetésével a feladatok egyeztetése, megbeszélése céljából. Visszaérkezése után a balassagyarmati határőr kerület parancsnoka tájékoztatta a helyetteseit az elhangzottakról. Berendelték a forgalomellenőrző pontok parancsnokait és a vezető beosztású tiszteket még 1968. VII. 29-én hajnalban. Ugyanezen a napon már megérkezett a megerősítő állomány Csornáról és Sopronból, a tisztes iskolákból. Délutánra tiszti figyelő járőröket küldtek ki az államhatárra. A nagy sietség jelzi, mindenki arra számított, hogy már július végén sor fog kerülni a határátlépésre, órákon, esetleg néhány napon belül.

Ezzel szemben csak 1968. VIII. 19-én érkezett el a végső felkészülés, az utolsó intézkedések megtételének ideje. Az országos parancsnok 1968. VIII. 21-én kelt jelentéséből ${ }^{27}$ tájékozódhatunk a történtekröl.

- 1968. VIII. 19-én 080ㅡ-ra az országos parancsnok berendelte a 9. és 10. (Miskolc, Balassagyarmat) kerületek valamint az önálló zászlóalj parancsnokait és az országos parancsnokság operatív bizottság tagjait, megtartották az eligazításokat.

- 1968. VIII. 20-án három vezetö tisztet küldött le a kerületekhez, a tisztek módosításokat vittek.

- 1968. VIII. 20-án 12으 órakor az országos parancsnok felbontotta a „Vadvirág” fedőnevü borítékot, amely a belügyminiszter 0020/68. számú parancsát és a 011/68. számú utasítását tartalmazta. Ennek megfelelően intézkedett arra, hogy a kerületek (1, 9, 10, Csorna, Miskolc, Balassagyarmat és az önálló zászlóalj) 180ㅡ-kor bontsák fel a „Bodrog” borítékot, majd az önálló zászlóaljnak $18^{50}$-re, a 9. kerületnek $18^{55}$-re, a 10. kerületnek 1900-ra, az 1. kerületnek pedig 1930-ra kellett jelentenie elhatározását, azaz minden vezetővel beszélt az országos parancsnok öt percet.

Megadta a „CS” időt 1968. VIII. 20-án 2400-ra. Ez az időpont a határátlépés ideje volt a Magyar Néphadsereg kijelölt alakulatai, valamint a szovjet haderő csapatai számára.

Meghatározta a lefegyverzés megkezdésének időpontját, „Cs”-15-re (határátlépés előtt tizenöt perccel) a határátlépések helyein, melyet a 10. kerület 1. és 2. örsén „CS”-kor, a többi helyen pedig „CS” +30-kor kellett megkezdeni.

\section{A határőrségi feladatok menete, időpontok}

A balassagyarmati határőr kerület parancsnoka 1968. VIII. 19-én az országos parancsnoktól és a Magyar Néphadsereg kijelölt hadosztályának parancsnokától kapott kiegészítő feladatokat, melyek már jelezték a határátlépésre vonatkozó végleges döntés megszületését. 1968. VIII. 20-án 180ㅡ- kor kapott feladatot a „Bodrog” jelzésü boríték felbontására. A legnehezebb feladat talán a csehszlovák szervekkel történő kapcsolat felvétele és a tervezett intézkedések megértetése volt.

1968. VIII. 20-án csehszlovák rádiózavarást észleltek, $18^{10}$ kor a határőrség érintett alakulatainál harci riadó rendeltek el a megerősítő állomány részére és azok kiindultak az alegységek megerősítésére. „23,45-órakor a Balassagyarmati, Parassapusztai, Szobi Forgalomellenörzö Pontokon, Letkési örsön, Balassagyarmati örsön, végrehajtották a csehszlovák FEP-ek és örsök elfoglalását."28

„A Somosköújfalui FEP-en Ipolytarnóci FEP-en és a többi örsön 24,00-órakor végrehajtották a FEP-ek és örsök elfoglalását, illetve megkezdték a csendör örsök elfoglalását." 29

„,24,00órakor a MNH alakulatai Balassagyarmat, Parassapuszta, Letkés irányában átlépték az államhatárt." 30

„Határövezet létrehozása a ker. pk. elvárs utasitására. ",,20,00-órától az alegységeink megerösitett szolgálattal örzik a Magyar Népköztársaság államhatárát." 31 
1968. VIII. 21-én 16ํㅡ-tól megtörtént a határzár részleges feloldása a kint rekedt magyar állampolgárok csoportos beléptetése.

1968. VIII. 21-én 0500-ig kivonták a határőr erőket csehszlovák területről, 1968. VIII. 21-én 00ํ﹎ tól szünetelt a határforgalom. A magyar területen rekedt csehszlovák, lengyel (Magyarnándor), NDK (Nógrádkövesd) állampolgárokat három különböző helyre tanácsokhoz irányították ahol segítséget kaptak a nem várt magyarországi tartózkodáshoz. Szintén ezen a napon, 1968. VIII. 21-én három időpontban $16^{00}, 18^{00}$ és $20^{00}$-kor Magyarországra csoportos beléptetések történtek az átkelöhelyeken.

1968. VIII. 22-én megszünt a határövezet, megindult a forgalom a magyar, csehszlovák, NDK lengyel állampolgárok részére.

1968. VIII. 23-án megindult a vasúti személyforgalom a szobi vonalon, 1968. VIII. 29-én pedig a somoskóúffalui vonalon is megindult a teherforgalom a vasúton.

1968. VIII. 25-én a karhatalmi erők Párkányban [Sturovó] láttak el feladatot 1968. VIII. 27-ig, utána itthon a határör őrsökre kerültek megerősítésül.

1968. IX. 08-án történt az utolsó bejegyzés a balassagyarmati hadműveleti naplóban. A megerősítő tisztes iskolák személyi állományát ekkor visszaindították a kiképzési helyükre.

Az 1968. IX. 21-én kelt országos parancsnoki jelentés ${ }^{32}$ kitekintést adott a bekövetkezett eseményekröl.

A csehszlovák forgalomellenőrző pontok és csendőr őrsök ellenállást nem tanúsítottak, a Sztránai csendőr örsön nem akarták átadni a fegyvereket.

A határon az átlépést a szovjet és magyar csapatok Rajkán 1968. VII. 20-án 23ํㅡ-kor, Komáromnál 1968. VII. 20-án 23드-kor, Medvehídnál 1968. VII. 20-án 235-kor, Letkésnél - Balassagyarmatnál - Ipolyságnál [Sahy] 1968. VII. 20-án 2400-kor megkezdték.

Ipolyhídvégnél egy magyar határör a túloldali csendőr laktanyánál 1968. VII. 21. 01ํㅡ-kor szolgálati fegyverét használta, mivel a csendőr járőr nem akarta fegyverét átadni és szökni próbált. Ennek következtében egy fö csehszlovák csendőr könnyebben megsebesült. Oroszváron [Rusovce] a csendőr örsön kilenc fö megtagadta a fegyvere átadását, őket őrizetbe vették, majd a parancsnokuknak adták át a magyar határörök.

A nyugati és déli kerületek parancsnokait 1968. VII. 20-án 22ํㅡㅁa berendelték és elrendelték nekik a „Bakony” nevü boríték felbontását.

A Magyar Néphadsereg 1968. VII. 21-én 02ํㅡㅁokor teljes légtérzárást rendelt el.

A 10. határőr kerülettel szemben lévő valamennyi túloldali határőrizeti szervezeti egység személyi állományának, a 9. kerületnél pedig 11 csendőr őrs tagjainak visszaadták a szolgálati fegyvereiket.

Ezek az őrsök biztosították a határszakaszt, a Töketerebes járásban három őrs nem kapta vissza fegyvereit szovjetellenes magatartás miatt.

A magyar határőrség személyi állományának hangulata jó volt. Az intézkedések megkezdése óta egy befelé irányuló határsértés fordult elő az Aggteleki Határőr Örsön.

\section{Események a tevékenység folyamán}

A kapcsolat a magyar és a csehszlovák határőrizeti szervezetek között még hosszabb ideig fagyos volt. A túloldali vámosok és útlevélkezelők sztrájkba léptek. 1968. VIII. 26-án Balassagyarmatról jelentették, hogy három-négy hely kivételével jó a kapcsolat, de nem javult Szob és Párkány [Sturovó] között. A határörség írásos propaganda anyagot (röplapokat) terjesztett a túloldalon a csendőrségnél, útlevélkezelőknél, vasutasoknál, eleinte nem sok eredménnyel. Sokan nem voltak hajlandók átvenni azokat.

A belépő vonatokra a magyar és szovjet beavatkozást elítélő feliratokat és rajzokat helyeztek el. Ezeket továbbindulás előtt letisztították. A mozdonyok elején található szocialista állami címert átfestették a cseh polgári címerre, a határállomáson ezt lemosták, majd a Keleti pályaudvaron a mozdonyvezetők visszafestették, stb. Belépö vonatokon, tehervagonokon felfestett vörös csillagok és horogkeresztek egyenlőség jellel jelentek meg, valamint „Lenin ébredj, megbolondult Brezsnyev” mondatokat is felfestettek más szovjet és magyarellenes feliratok társaságában. ${ }^{33}$

Bár a magyar határőrök határon túli alkalmazását a továbbiakban nem tervezték, Balassagyarmatról mégis 96 fớt kellett átküldeni Párkányba [Sturovó], akik részt vettek egy laktanya biztosításában, rádióadó, és fegyver-lőszer raktár valamint a városi távbeszélő központ őrizetében.

Amikor megkezdődött a Magyar Néphadsereg és a szovjet haderő Csehszlovákia megszállásában résztvevő alakulatainak a visszavonása, az országos parancsnokság távmondatban ${ }^{34}$ értesítette a határör kerületeket a határon történő áthaladás menetrendjéröl. A tervek szerint 1968. X. 21. és 1968. X. 23. között léptek be a magyar és szovjet csapatok visszafelé jövet a Magyar Népköztársaság területére. Szobnál 1968. X. 21-30 között 25-30 szovjet szerelvény érkezett. Megszervezték az ünnepélyes foga- 
dás rendjét, az átkelöhelyeket feldíszítették vörös és nemzeti színü zászlókkal, a közutakon a civil forgalom szünetelt a belépés idejére.

\section{A szomszédos országok reagálása}

Jugoszlávia tekintetében néhány dokumentum erejéig rendelkezünk kitekintéssel a szomszédos országok reakciójára. ${ }^{35}$

Jugoszláviában, Palicson több száz csehszlovák állampolgárt helyeztek el. Jugoszláv személyek agitálták őket, hogy Ausztrián keresztül utazzanak ki és Bécsben a csehszlovák nagykövetségen jelentkezzenek. Olyan anyagokat osztottak ki közöttük, amelyek elítélik a Csehszlovákiába történt bevonulást. Ezeket az anyagokat a magyar határörök a magyar határátkelőhelyeken az utasoktól bevonták.

A jugoszláv fél reagálását a csehszlovákiai bevonulásra egy belügyminiszter-helyettesnek küldött határörség törzsfönöki jelentés foglalta össze. ${ }^{36}$

A jugoszláv szervek által foganatosított intézkedések:

- katonai mozgást lehetett észlelni az ország területén;

- elhalasztották a sorköteles szolgálatot teljesítő személyi állomány soron lévő leszerelését;

- tartalékosokat hívtak be;

- két fös járőrözést vezettek be a határőrségnél, járőrcsoportokat alkalmaztak, megszállták az üres határőr őrsöket (karolákat);

- tábori körleteket és védelmi állásokat építettek ki 5-7 kilométerre az államhatártól;

- páncélozott jármüvek jelentek meg, a rendőrség megerösített járőrözést folytatott, hidakat aknáztak alá, a dunai flotta nyolc hajóját felvontatták Kiskőszeg térségébe;

- légi figyelést végeztek;

- augusztus és szeptember hónapban a magyar-jugoszláv államhatáron a személyforgalom félmillióval, a jármüforgalom pedig százezerrel csökkent;

- adatokat gyüjtöttek az utasoktól;

- nyugállományú belügyi tisztek gyakran utaztak be felderítési céllal Magyarországra;

- a vegyes bizottságok tovább múködtek (ezek a bizottságok a határrendet sértő események rendezéséért voltak felelősek);

- előzetesen már egyeztetett magyar-jugoszláv közös programokat lemondtak;

- a Jugoszláv Kommunisták Szövetsége tagjait löfegyverrel szerelték fel;

- 200000 embert hívtak be katonai szolgálatra.

Romániában a határörizeti szervek megerösített szolgálatot vezettek be, melyet több fős járőrözéssel valósítottak meg. Megerősödött a magyarellenes propaganda. Ismeretlen személyek megrongálták a Romániába utazó magyar turisták gépjármủveit. Elhalasztották a román hadseregben sorkatonai szolgálatot teljesítő katonák leszerelését. Ebben az időben a román haderőben 16 hónapos katonai szolgálatot teljesített a sorozott állomány. Felerősödött a népi milícia védelmi feladatok teljesítésére irányuló kiképzése. A román hatóságok megerősítették a szovjet-román határ védelmét.

Ausztriában a csendőrségnél megerősített szolgálatot rendeltek el és a testület erőit átcsoportosították a csehszlovák államhatárra. Az osztrák sorkatonák szolgálati idejét hat héttel meghosszabbították. ${ }^{37}$

Összességében megállapítható, hogy 1968-ban a magyar határőrség is részt vett a csehszlovákiai bevonulás biztosításában és annak során részfeladatokat látott el. Mivel a katonai intervenció szövetségi politikai döntés alapján történt az alól egyetlen hazai fegyveres szervezet sem vonhatta ki magát. A magyar határőrség struktúrája, felszerelése és felkészítése azonban nem tette lehetővé harcászati tevékenységben történő alkalmazását. Szerencsére erre a Magyar Néphadsereg csapatai esetében sem került sor.

A határőrségre kirótt feladatokat — amelyek lényegében nem harcászati jellegüek voltak — a határör alegységek probléma nélkül ellátták. Képességeiket az igénybevételt elrendelő politikai/katonai vezetés jól mérte fel és ennek megfelelően teljesíthető feladatokat szabott meg a testület számára.

A határőrség erői nem bizonyultak elegendőnek a teljes magyar államhatár biztonságos őrzésére, mivel az osztrák és jugoszláv államhatárokon is megerősített szolgálatellátást kellett bevezetni. A határőr kerületek megerősítését ekkor még probléma nélkül lehetett megoldani a karhatalom zászlóaljaitól, illetve szoros együttmüködést szerveztek a Magyar Néphadsereggel, a rendőrséggel, valamint a Vám- és Pénzügyörséggel, egyes esetekben a munkásőrséggel.

A határátlépéshez és határbiztosításhoz kapcsolódó feladatokat már 1968 júliusában megszervezték, sőt az erők egy részét már 1968. VII. 27-én északra, Balassagyarmatra és Miskolcra csoportosítot- 
ták. Ez azt mutatja, hogy az akció felkészítése egy hónapot vett igénybe a politikai elhatározás megszületésétől számítva. Az országos parancsnok írásos parancsban szabályozta, a sajátosságoknak megfelelően eltérő tartalommal, valamennyi határör kerület és a Győri Önálló Zászlóalj tennivalóit. A határőr kerületek parancsnokai ennek megfelelően elhatározást hoztak és széleskörü, aprólékos tervezést végeztek.

A hivatásos és sorállomány részére az agitációs és propaganda szervek hónapokkal megelőzően aktív kampányt folytattak, nagy számú „,politikai foglalkozást” tartottak melyeken a beavatkozás szükségességét magyarázták. Kirívó fegyelmi probléma a tevékenység során nem fordult elő, haláleset nem következett be. A Magyar Néphadsereggel ellentétben a határőrség nem alkalmazott tartalékos állomány, a „bent lévő” katonákkal oldották meg a tennivalókat.

\section{Jegyzetek:}

${ }^{1}$ SALLAI: A BM és a határőrség feladatai Csehszlovákia 1968-as megszállásában.

${ }^{2}$ DEÁK: A Belügyi Szemle és az ideológiai háború a helsinki konferenciáig 1953-1975. 61.p. ; Idem: The state security articles of the Interior Ministry Review prospectus at the service of the current politics and the internal affairs propaganda (1963-1972). [Állambiztonsági ügyek a Belügyi Szemlében az aktuálpolitika és a belügyi propaganda szolgálatában.] ; Idem: A Belügyi Szemle Tájékoztatójában a médiával kapcsolatban megjelent anyagok (1963-1972).

${ }^{3}$ SALLAI: The participation of the Hungarian Border Guards in the 1968 occupation of Czechoslovakia. [A Magyar Határörség részvétele a Csehszlovákia 1968-as megszállásában.]

${ }^{4}$ A határőrizeti teendőket megvalósító testület katonai jellegü szervezetként való müködtetése nem feltétlenül szovjet indíttatású pártállami hagyomány, hiszen Magyarországon a trianoni békediktátum egyik következménye volt, hogy a határőrizeti testület a magyar haderő vonzáskörébe került kezdetben rejtetten, majd a fegyverkezési egyenjogúságot kimondó 1938. évi Bled-i egyezmény nyomán nyíltan is. A pártállami csavar „csupán” az volt, hogy nem a honvédelmi tárca, hanem az ÁVH, majd a belügyi tárca alárendeltségébe helyezték a határörséget. (a szerk.)

${ }^{5}$ HAUTZINGER: 67.p.

${ }^{6}$ Érdekes a szerző okfejtése, mely szerint a harcászati teendőkre való alkalmatlansága miatt a határőrség nem sorolható a fegyveres erők közé. A testületet azonban nem is kívánták felvértezni harcászati képességekkel, mivel azokra a határok eredményes őrzése érdekében nem volt szükség. A szervezet a fegyveres erőkhöz nem a harcászati képességei miatt tartozott, hanem azért mert a személyi állományának a tagjai katonák voltak. Őket a katonákra általában vonatkozó jogosultságok megillették, illetve kötelezettségek terhelték. A szervezeten belüli függelmi viszonyok pedig nem hivatalnokiak, hanem katonaiak voltak. Ezek voltak azok a döntő körülmények, amelyek alapján a határőrséget a fegyveres erők közé sorolták. ( $a$ szerk.)

${ }^{7}$ MNL-OL. HOP. XIX-B-10. 9. sz.doboz 1968 év I/9. tárgykör 73. folyószám. Jelentés. „A „Bodrog” fedőnevű gyakorlattal kapcsolatos intézkedések kiadása"1968. július 29.

${ }^{8}$ Loc.cit.

${ }^{9}$ Loc.cit. „Parancs”

${ }^{10}$ Loc.cit.

${ }^{11}$ Loc.cit.

12 Loc.cit.

${ }^{13}$ Loc.cit.

${ }^{14}$ Loc.cit.

${ }^{15}$ Loc.cit.

${ }^{16}$ Loc.cit.

${ }^{17}$ Loc.cit.

${ }^{18}$ Loc.cit.

${ }^{19}$ Loc.cit.

${ }^{20}$ Loc.cit.

${ }^{21}$ Loc.cit.

${ }^{22}$ Loc.cit.

${ }^{23}$ Loc.cit.

${ }^{24}$ Loc.cit.

${ }^{25}$ Loc.cit. A Balassagyarmati Határőr Kerület parancsnokának elhatározása.

${ }^{26}$ Loc.cit. Hadmüveleti Napló „Bodrog”.

${ }^{27}$ Loc.cit. 168. folyószám. Országos parancsnok 1968. VIII. 21-ei jelentése a miniszterhelyettesnek.

${ }^{28}$ Loc.cit. 73. folyószám. Hadműveleti Napló „Bodrog”.

${ }^{29}$ Loc.cit.

${ }^{30}$ Loc.cit. 
${ }^{31}$ Loc.cit.

${ }^{32}$ Loc.cit. 168. folyószám. Országos parancsnok 1968. VIII. 21-ei jelentése a miniszterhelyettesnek.

${ }^{33}$ Loc.cit. 101. folyószám. Napi jelentés.

${ }^{34}$ Loc.cit. 167. folyószám. Értesítés.

${ }^{35}$ Loc.cit. 172. folyószám. „Összefoglaló” a kerületparancsnokságok jelentéseiből” augusztus 27.

${ }^{36}$ Loc.cit. 175. folyószám. Jelentés. „Tárgy: Jugoszláv szervek és képviselőik magatartása a csehszlovákiai eseményekkel kapcsolatban" október. 15.

${ }^{37}$ Dr. NAGY József volt az első kutató, aki az 1968. évi csehszlovákiai bevonulásban a határőrség szerepét feltárta, tisztázta a testületnek az intervencióban betöltött helyét. Sajnálatos módon további levéltári kutatásaiban megakadályozta a 2005-ben bekövetkezett halálos kimenetlü autóbalesete. (a szerk.)

NAGY: 79-84.p.

Forrás- és irodalomjegyzék (a jegyzetekben alkalmazott röviditések oldása):

\section{TANULMÁNYOK}

DEÁK József: A Belügyi Szemle Tájékoztatójában a médiával kapcsolatban megjelent anyagok (1963-1972).

$(2 . ;)$

DEÁK: The state security articles of the Interior Ministry Review prospectus at the service of the current politics and the internal affairs propaganda (19631972). [Állambiztonsági ügyek a Bel-ügyi Szemlében az aktuálpolitika és a belügyi propaganda szolgálatában. (1963-1972).] (2.;)

DEÁK: A Belügyi Szemle és az ideológiai háború a helsinki konferenciáig 1953-1975.

\section{HAUTZINGER}

(5.;)

NAGY

(37.;)

SALLAI: The participation of the Hungarian Border Guards in the 1968 occupation of Czechoslovakia. [A Magyar Határőrség részvétele a Csehszlovákia 1968-as megszállásában.]

(3.;)

SALLAI: A BM és a határőrség feladatai Csehszlovákia 1968-as megszállásában.

(1.;)

\section{LEVÉL-, IRAT- ÉS DOKUMENTUMTÁRI GYÜJTEMÉNYEK}

MNL-OL. HOP.

(7.;8.;9.;10.;11.;12.;13.;14.;15.;16.;

17.;18.;19.;20.;21.;22.;23.;24.;25.;26.;

27.;28.;29.;30.;31.;32.;33.;34.;35.;36.; 1803-7356. 1416-3845.
DEÁK József: A Belügyi Szemle Tájékoztatójában a médiával kapcsolatban megjelent anyagok (1963-1972). Magyar Rendészet, XIV.évf. (2014) 2.sz. 127-137.p. HU-ISSN 1416-3845.

- DEÁK József: The state security articles of the Interior Ministry Review prospectus at the service of the current politics and the internal affairs propaganda (1963-1972). [Állambiztonsági ügyek a Belügyi Szemlében az aktuálpolitika és a belügyi propaganda szolgálatában. (1963-1972).] Central European Papers, II.évf. (2014) 1.sz. 150-159.p. PL-ISSN 2336-369X.

DEÁK József: A Belügyi Szemle és az ideológiai háború a helsinki konferenciáig 1953-1975. 57-70.p. In: PARÁDI József et. al. (szerk.): Ünnepi tanulmányok Gáspár László 65. születésnapja tiszteletére. Budapest, 2015, Szemere Bertalan Magyar Rendvédelem-történeti Tudományos Társaság. 154 p. HU-ISBN 978615803090 8. /Salutem, 1./ HU-ISSN 2416-2078.

- HAUTZINGER Zoltán: A fegyveres szervek rendeltetésének alaptörvényi szabályozása. 65-75.p. In DRINóczI Tímea (szerk.): Magyarország új alkotmányossága. Pécs, 2011, Pécsi Tudományegyetem Állam- és jogtudományi Kar. 229 p. HU-ISBN 9789636424374.

- NAGY József: A magyar határőrség tevékenysége a csehszlovákiai beavatkozás időszakában. Rendvédelem-történeti Füzetek (Acta Historiae Praesidii Ordinis), XI.évf. (2005) 14.sz. 79-84.p. HU-ISSN 1216-6774.

SALLAI János: The participation of the Hungarian Border Guards in the 1968 occupation of Czechoslovakia. [A Magyar Határörség részvétele a Csehszlovákia 1968-as megszállásában.] Prague Papers On The History Of International Relations, XVII.évf. (2013) 2.sz. 184-197.p. CZ-ISSN

SAllai János: A BM és a határőrség feladatai Csehszlovákia 1968-as megszállásában. Magyar Rendészet, XIII.évf. (2014) 159-170.p. HU-ISSN

MNL (Magyar Nemzeti Levéltár) OL (Országos Levéltár) HOP (Határőrség Országos Parancsnoksága iratainak gyüjteménye) 